\title{
The Short Form-6 Dimension (SF-6D) Validity and Reliability in Hemodialysis Patients
}

Anisa Zulfa Fatihah ${ }^{1 *}$, Tri Murti Andayani ${ }^{2}$, Nanang Munif Yasin ${ }^{2}$

${ }^{1}$ Program Studi Magister Farmasi Klinik, Fakultas Farmasi, Universitas Gadjah Mada, Yogyakarta, Indonesia

${ }^{2}$ Departemen Farmakologi dan Farmasi Klinik, Fakultas Farmasi, Universitas Gadjah Mada, Yogyakarta, Indonesia

*Corresponding author: zulfafatihah16@gmail.com

Submitted: 18 September 2020

Accepted: 22 Desember 2020

Published: 29 Agustus 2021

\begin{abstract}
Background: Quality of life becomes an important parameter that is needed for assessing the clinical outcome of patients undergoing long-term therapy for chronic diseases, such as chronic kidney failure. Short Form-6 Dimension (SF-6D) is one of the generic instruments that can be used to assess health-related quality of life (HRQOL). The psychometric properties SF-6D test in hemodialysis patients in Indonesia has never been conducted. Objective: Aimed to evaluate the reliability and validity of SF-6D questionnaire in Indonesian version in patients with chronic kidney failure. Methods: This is an observational study with a cross-sectional design involving 117 patients who meet the inclusion and exclusion criteria in the hemodialysis unit in Dr. Sardjito Central General Hospital and UGM Academic Hospital Yogyakarta. Results: The SF-6D questionnaire has good internal consistency, as seen in Cronbach's alpha value of 0.771. In this study, the ceiling effect test showed $6.8 \%$ $(<15 \%)$. The measurement of convergent validity was carried out using Spearman rho to analyze the correlation of the questionnaires and see its correlation with other instruments (KDQOL-SF36). Based on the research, the correlation coefficient value of 0.768 (> 0.75) indicates very good result for a strong correlation. The SF- $6 D$ instrument was able to distinguish the quality of life with a significant value $(p<0.05)$ in age, occupation, and comorbid groups. Conclusion: SF-6D questionnaire is valid and reliable, so it can be used to measure the HRQOL of hemodialysis patients. The mean SF-6D utility score of hemodialysis patients is high (0.7975 \pm 0.1488$)$.
\end{abstract}

Keywords: hemodialysis, psychometric properties, quality of life, SF-6D

\begin{abstract}
Abstrak
Pendahuluan: Kualitas hidup menjadi parameter penting yang diperlukan dalam menilai luaran klinis pasien yang menerima terapi penyakit kronis jangka panjang seperti gagal ginjal kronis. Penilaian kualitas hidup menjadi outcome kesehatan yang penting untuk diukur pada studi evaluasi farmakoekonomi. Short Form- 6 Dimension (SF-6D) merupakan salah satu instrumen generik yang dapat digunakan untuk menilai HRQOL. Pengujian psychometric properties SF-6D pada pasien hemodialisis di Indonesia belum pernah dilakukan. Tujuan: Untuk mengevaluasi reliabilitas dan validitas kuesioner Short Form- 6 Dimensions (SF-6D) versi bahasa Indonesia pada pasien gagal ginjal kronis. Metode: Penelitian bersifat observasional dengan desain cross sectional yang melibatkan 117 pasien yang memenuhi kriteria inklusi dan eksklusi di unit hemodialisis Rumah Sakit Umum Pusat Dr. Sardjito dan Rumah Sakit Akademik UGM Yogyakarta. Hasil: Kuesioner SF-6D memiliki internal consistency yang baik, yang ditunjukkan dengan nilai Cronbach's alpha 0,771. Pada penelitian ini pengujian ceiling effect menunjukkan hasil 6,8\% (< 15\%). Pengukuran convergent validity dilakukan dengan uji non-parametrik menggunakan Spearman rho, untuk menganalisis hubungan kuesioner, melihat korelasinya dengan instrumen lain (KDQOL-SF36), dihasilkan nilai koefisien korelasi sebesar 0,768 (>0,75) menunjukkan sangat baik untuk korelasi yang kuat. Instrumen SF-6D dapat membedakan kualitas hidup bernilai signifikan $(\mathrm{p}<0,05)$ pada kelompok usia, pekerjaan dan komorbid. Kesimpulan: Kuesioner SF-6D valid dan reliabel digunakan untuk mengukur HRQOL pasien hemodialisis. Rata-rata skor utilitas SF-6D pasien hemodialisis tergolong tinggi $(0,7975 \pm 0,1488)$.
\end{abstract}

Kata kunci: hemodialysis, kualitas hidup, psychometric properties, SF-6D 


\section{INTRODUCTION}

The measurement of health-related quality of life (HRQOL) is getting common as an important indicator of health in recent years, including in assessing the clinical outcomes of patients undergoing long-term therapy for chronic diseases, such as chronic kidney failure. The importance of involving quality of life indicators in the clinical management of patient is due to the relationship between quality of life and clinical outcomes. Thus, in recent years, quality of life assessment has become an important health outcome to measure in pharmacoeconomic evaluation study. In cost-utility analysis (CUA), a pharmacoeconomic evaluation method, outcomes are measured in qualityadjusted life-year (QALYs), which also measure the quality of life. A generic instrument has been created to generate a single value on quality of life and allows for the measurement of CUA (Cost-Utility Analysis). Short Form-6 Dimension (SF-6D) is a measuring tool (generic instrument) that can be used to assess HRQOL. This questionnaire has been widely used to assess health status by several countries, but the evaluation may differ in each country due to differences in health care systems (Collister et al., 2016; Kularatna et al., 2019; Poder \& Gandji, 2016; Wyld et al., 2016). HRQOL research in hemodialysis patients in Indonesia using the SF-6D questionnaire is still limited. The Short Form-6 Dimension (SF-6D) has been used in several research in hemodialysis patients (Pan et al., 2018; Wyld et al., 2016; Yang et al., 2015). The research show that the SF$6 \mathrm{D}$ measurement results are better than the EQ-5D instrument in detecting various stages of disease and predicting a severe disease burden, such as chronic kidney failure, with little floor effect. The SF-6D is also better at describing differences among patients who are at the top of the measurement scale with a small ceiling effect (Kularatna et al., 2019; Thaweethamcharoen et al., 2019).

To assess quality of life in hemodialysis patients, valid and reliable measurement instruments must be used, so the Indonesian version of the SF-6D instrument must be tested for its psychometric properties. The Indonesian version of the valid and reliable SF-6D instrument can be used for pharmacoeconomic studies and as a tool for measuring quality of life in order to provide meaningful implications for decision-making in Indonesian national policy. In Indonesia, no SF-6D psychometric properties test has ever been performed on patients with chronic kidney failure.

\section{MATERIALS AND METHOD}

\section{Materials}

Medical records from hemodialysis patients and data from interviews were used in the study. The data include respondent characteristics such as gender, age, education level, occupation, income, and comorbidities.

\section{Equipment}

The instrument used is a generic Short Form-6 Dimension questionnaire (SF-6D). The Short Form-36 instrument (SF-36) is a classification system for assessing six health domains: physical function, role limitation, social function, mental health, body pain, and vitality. Each dimension of the SF-6D has four levels up to six levels, where the respondents can choose one statement (level) from each of these dimensions. The SF-6D scoring algorithm was developed using the standard gamble (SG) method from a sample of $249 \mathrm{SF}$ $6 \mathrm{D}$ health levels from a representative sample of the UK population (Brazier et al., 2002). The scoring consists of the healthy and unhealthy categories, where level 1 in each dimension describes that the patient is healthy and does not have a functional limitation, so the patient is given a score of 111111, which indicates that the respondent is perfectly healthy, while the lowest score is 645655. The score is then converted into a utility value of 0.29 to 1.0 using the SF-Converter program developed by the University of Sheffield. The SF-6D questionnaire is available in the Indonesian version, and it has been tested for its validation and reliability to the population in Yogyakarta City, where the results of the internal consistency reliability test show the Cronbach alpha coefficient value of $0.752(\mathrm{r}>0.5)$, which indicates that the Indonesian version of the SF-6D instrument has good reliability (Andayani et al., 2020).

\section{Method}

\section{Design and subject of research}

This is an observational study with a cross-sectional design that was carried out from February to March 2020 at the hemodialysis unit of Dr. Sardjito Central General Hospital and UGM Academic Hospital in Yogyakarta. Based on the calculation of the minimum sample size, the number of respondents involved in this study was 117 patients. The inclusion criteria were patients aged 18 years and above, patients with endstage chronic renal failure who had been on routine hemodialysis for at least 3 months prior to the study, patients who could communicate well, and patients who agreed to participate in this study by signing an informed consent form. Meanwhile, patients whose general condition was weak or uncooperative were excluded from the study, as were patients who were unable to 
follow the process in the middle of the interview for data collection due to conditions, such as nausea, vomiting, cramps to seizures, or who were psychologically affected by the condition of other patients, and patients with incomplete medical records. The ethics committee of the Faculty of Medicine UGM - Dr. Sardjito Central General Hospital, Yogyakarta, granted permission for this study (Ref. No.: KE/FK/0191/EC/2020).

\section{Statistics analysis}

All of the processes of analysis was performed using SPSS version 23. Instrument reliability was assessed using Cronbach's Alpha reliability. Construct validity is measured using convergent validity and known group validity. The statistical test of convergent validity was carried out using Spearman's rank correlation. To test and analyze the correlation of the questionnaire, its correlation with other instruments that measure the same trait or concept (KDQOL-SF36) was examined. The correlation value is interpreted using the following criteria: a value of $0-0.25$ means there is no correlation, a value of $0.25-0.5$ means there is a correlation, a value of 0.5 - 0.75 means moderate for a good correlation, and a value of more than 0.75 means very good for a strong correlation (Portney \& Watkins, 2000). Known group validity was used to test discriminatory validity. Respondents will be grouped based on socio-demography and then the differences would be seen for several test groups. Mann-Whitney U test was used on the variables of gender, occupation and Kruskal-Wallis $\mathrm{H}$ test was used for variables of age, education, marriage and history of disease.

\section{RESULTS AND DISCUSSION}

\section{Socio-demography of patients}

This study involved 117 hemodialysis patients, which were dominated by males $(54.7 \%)$ compared to females $(45.3 \%)$, with a mean SD of patient age of 50.7 \pm 13.3 years (Table 1$)$. Percentage of age included 18 40 years $(24.8 \%)$ 41-60 years $(46.2 \%)$ and 60 years $(29.1 \%)$. The prevalence of male hemodialysis patients is due to lifestyle factors such as smoking, obesity, and metabolic syndrome, all of which play a role in the progression of kidney disease severity (Agency for Health Research and Development, 2019; Halbesma et al., 2008).

Table 1. Socio-demography of hemodialysis patients

\begin{tabular}{|c|c|c|}
\hline Characteristics of Patients & $\begin{array}{l}\text { The Number of Subject } \\
\qquad(\mathrm{n}=117)\end{array}$ & $\begin{array}{l}\text { Percentage } \\
(\%)\end{array}$ \\
\hline \multicolumn{3}{|l|}{ Sex } \\
\hline Male & 64 & 54.7 \\
\hline Female & 53 & 45.3 \\
\hline \multicolumn{3}{|l|}{ Age } \\
\hline $18-40$ years & 29 & 24.8 \\
\hline $41-60$ years & 54 & 46.2 \\
\hline$>60$ years & 34 & 29.1 \\
\hline \multicolumn{3}{|l|}{ Job Status } \\
\hline Employed & 37 & 31.6 \\
\hline Unemployed & 80 & 68.4 \\
\hline \multicolumn{3}{|l|}{ Education Level } \\
\hline$<$ High School & 19 & 16.2 \\
\hline High School & 61 & 52.1 \\
\hline College & 37 & 31.6 \\
\hline \multicolumn{3}{|l|}{ Duration of Hemodialysis } \\
\hline$<1$ year & 13 & 11.1 \\
\hline $1-5$ years & 64 & 54.7 \\
\hline$>5$ years & 40 & 34.2 \\
\hline \multicolumn{3}{|l|}{ Comorbidity } \\
\hline Hypertension & 76 & 65.4 \\
\hline Hypertension, DM & 41 & 34.6 \\
\hline
\end{tabular}

The proportion of kidney failure patients with a high school education (senior high school) was higher $(55.1 \%)$ than the proportion of patients with a basic education (elementary and junior high school: 14.1\%) and college education (30.8\%). Patients were classified as employed or unemployed based on their employment status. The percentage of unemployed patients in both therapy groups was 66.7 percent, which was higher than the percentage of unemployed patients in the control group $(33.3 \%)$. In line with other studies, retirees and housewives predominated among unemployed patients (Kalsoom, 2019). 
In this study, most patients with chronic kidney failure were also had comorbid hypertension (65.4\%) compared to comorbid hypertension and diabetes mellitus (34.6\%). This finding was consistent previous studies showing that comorbid of hypertension was more common in hemodialysis patients compared to diabetes and hypertension (Cha \& Han, 2020; (Sihombing, 2019). The highest percentage were patients with hemodialysis duration of $1-5$ years (Cha \& Han, 2020; Sihombing, 2019). About 51.3\% followed by patients with hemodialysis duration of more than 5 years $(42.3 \%)$.

\section{Internal consistency reliability}

The value of Cronbach's Alpha reliability is presented in Table 2. Based on the psychometric property assessment conducted in this research, it is seen that the SF-6D questionnaire has good internal consistency, as indicated by Cronbach's alpha value of 0.771. Overall, the SF-6D questionnaire has a good reliability with Cronbach's alpha value of $>0.5$.

Table 2. Result of internal consistency cronbach's

\begin{tabular}{ccc}
\multicolumn{3}{c}{ alpha } \\
\hline $\begin{array}{c}\text { SF-6D } \\
\text { Domain }\end{array}$ & $\begin{array}{c}\text { Corrected } \\
\text { item-total } \\
\text { correlation }\end{array}$ & $\begin{array}{c}\text { Cronbach's } \\
\text { alpha if } \\
\text { item deleted }\end{array}$ \\
\hline $\begin{array}{c}\text { Physical } \\
\text { Function } \\
\text { Role }\end{array}$ & 0.580 & 0.720 \\
$\begin{array}{c}\text { Limitation } \\
\text { Social }\end{array}$ & 0.545 & 0.734 \\
$\begin{array}{c}\text { Function } \\
\text { Body Pain } \\
\text { Mental }\end{array}$ & 0.671 & 0.694 \\
Health & 0.589 & 0.737 \\
Vitality & 0.595 & 0.728 \\
\multicolumn{2}{c}{$\begin{array}{c}\text { Cronbach Alpha reliability }=0.771 \\
\text { (Nof domain }=6)\end{array}$} & 0.789 \\
\hline
\end{tabular}

The ceiling effect was investigated in this study. It is known that instruments with good content do not have a ceiling effect. The ceiling effect test was used to examine the distribution of responses from respondents. If more than $15 \%$ of respondents answered with perfect numbers, the instrument is said to have a ceiling effect.
The ceiling effect test resulted in a result of 6.8 percent (15 percent) in this study, indicating that the SF-6D instrument did not have a ceiling effect.

\section{Convergent validity}

Convergent validity is an analysis to see the validity of two instruments that measure the same concept or measure the concept with different methods. In this research, convergent validity was measured using a nonparametric test called Spearman's rho to test the correlation of the questionnaire and to see how it correlated with other instruments that measure the same trait or concept (specific questionnaire KDQOL-SF36). Because the obtained data were not normally distributed, they did not meet the requirements of the parametric test. This was noticed after performing a normality test on the data using the KolmogorovSmirnov statistical test, which resulted in a significance value of 0.000 (less than 0.05 ), indicating that the data is not normally distributed. Correlation analysis was performed using Spearman's rank correlation test between the utility value of SF-6D and KDQOL-SF36 score, resulting in a correlation coefficient of 0.768 (> 0.75), which indicates very good for a strong correlation. The higher the value of the correlation coefficient, the stronger the correlation and the better the validity of the instrument is. The correlation between the two instruments is significant because it has a significance value of less than 0.05 .

\section{Known-group validity}

This validity test was carried out to determine whether the SF-6D instrument was able to distinguish the quality of life of hemodialysis patients between groups of age, sex, education, occupation, disease history, and marital status in several SF-6D instrument domains. Based on the research results, the validity of each question item obtained from the significance value was shown. The results showed that the SF-6D instrument was able to distinguish the quality of life with a significant value in the age group, occupation, and comorbidities in several domains while other groups did not provide significant results. The results of the knowngroup validity test can be seen in Table 3 . 
Table 3. Results of Known Group Validity

\begin{tabular}{|c|c|c|c|c|c|c|}
\hline \multirow{2}{*}{ Characteristics } & \multicolumn{6}{|c|}{ SF-6D Domain } \\
\hline & $\mathrm{FF}$ & KP & FS & RS & KM & $\mathrm{V}$ \\
\hline $\begin{array}{c}\text { Sex } \\
p \text {-value }\end{array}$ & 0.827 & 0.618 & 0.593 & $0.005^{*}$ & 0.487 & 0.965 \\
\hline $\begin{array}{c}\text { Age } \\
p \text {-value }\end{array}$ & $0.000^{*}$ & $0.002 *$ & $0.003 *$ & 0.171 & 0.309 & 0.617 \\
\hline $\begin{array}{l}\text { Education } \\
p \text {-value }\end{array}$ & 0.229 & 0.599 & 0.115 & 0.046 & 0.469 & 0.133 \\
\hline $\begin{array}{l}\text { Occupation } \\
\text { p-value }\end{array}$ & $0.043^{*}$ & $0.033^{*}$ & $0.015^{*}$ & $0.010^{*}$ & $0.049 *$ & 0.305 \\
\hline $\begin{array}{l}\text { Income } \\
p \text {-value }\end{array}$ & 0.934 & 0.188 & 0.225 & 0.029 & 0.099 & 0.600 \\
\hline $\begin{array}{l}\text { Comorbidity } \\
p \text {-value }\end{array}$ & $0.000^{*}$ & $0.037^{*}$ & $0.011^{*}$ & 0.731 & 0.136 & 0.039 \\
\hline $\begin{array}{c}\text { Dialysis Duration } \\
p \text {-value }\end{array}$ & $0.020^{*}$ & 0.365 & 0.159 & 0.906 & 0.947 & 0.421 \\
\hline
\end{tabular}

Table 4. Assesment result of utility with short form 6 dimensions (SF-6D)

\begin{tabular}{lccccc}
\hline \multicolumn{1}{c}{ Quality of Life } & $\mathrm{N}$ & Percentage & Average \pm SD & $\begin{array}{c}\text { Minimal } \\
\text { Score }\end{array}$ & $\begin{array}{c}\text { Maximal } \\
\text { Score }\end{array}$ \\
\hline Utility score with & 117 & $100 \%$ & $\begin{array}{c}0.7975 \pm \\
0.1488\end{array}$ & 0.3483 & 1.000 \\
SF6D & 117 & &
\end{tabular}

\section{CONCLUSION}

In this research, a valid and reliable SF-6D questionnaire is used to measure the HRQOL of hemodialysis patients. The mean SF-6D utility score of hemodialysis patients is high $(0.79750 .1488)$ (Table 4$)$.

\section{REFERENCES}

Andayani, T. M., Kristina, S. A., Endarti, D., Haris, R. N. H. \& Rahmawati, A., 2020. Translation, Cultural Adaptation, and Validation of ShortForm 6D on the General Population in Indonesia. Value in Health Regional Issues; 21; 205-210.

Agency for Health Research and Development (Badan Penelitian dan Pengembangan Kesehatan). (2019). Laporan Nasional RISKESDAS 2018. Jakarta: Lembaga Penerbit Badan Penelitian dan Pengembangan Kesehatan.

Brazier, J., Roberts, J. \& Deverill, M. (2002). The Estimation of a Preference-Based Measure of Health from the SF-36. Journal of Health Economics; 21; 271-292.

Cha, J. \& Han, D., 2020. Health-Related Quality of Life Based on Comorbidities Among Patients with End-Stage Renal Disease. Osong Public Health and Research Perspectives; 11; 194-200.

Collister, D., Komenda, P., Hiebert, B., Gunasekara, R.,
Xu, Y., Eng, F., Lerner, B., Macdonald, K., Rigatto, C. \& Tangri, N. (2016). The Effect of Erythropoietin-Stimulating Agents on HealthRelated Quality of Life in Anemia of Chronic Kidney Disease: A Systematic Review and Metaanalysis. Annals of Internal Medicine; 164; 472 478.

Halbesma, N., Brantsma, A. H., Bakker, S. J. L., Jansen, D. F., Stolk, R. P., De Zeeuw, D., Jong, P. E. D. \& Gansevoort, R. T. (2008). Gender Differences in Predictors of the Decline of Renal Function in the General Population. Kidney International; 74; 505-512.

Kalsoom, U. (2019). Gender Role in Anxiety, Depression and Quality of Life in Chronic Kidney Disease Patients. Pakistan Journal of Medical Sciences; 36; 251-254.

Kularatna, S., Senanayake, S., Gunawardena, N. \& Graves, N. (2019). Comparison of the EQ-5D 3L and the SF-6D (SF-36) Contemporaneous Utility Scores in Patients with Chronic Kidney Disease in Sri Lanka: a Cross-Sectional Survey. BMJ Open; 9; 024854.

Pan, C.-W., Wu, Y., Zhou, H.-J., Xu, B.-X., dan Wang, P., 2018. Health-Related Quality of Life and Its Factors of Hemodialysis Patients in Suzhou, 
China. Blood Purification; 45; 327-333.

Poder, T. G. \& Gandji, E.W. (2016). SF6D Value Sets: a Systematic Review. Value in Health; 19; A282.

Sihombing, J. P. (2019). Cost-Effectiveness Analysis Eritropoetin Alfa Dibandingkan Dengan Eritropoetin Beta Pada Pengobatan Anemia Pasien Penyakit Ginjal Kronik Yang Menjalani Hemodialisis Rutin. Disertasi; Fakultas Farmasi Universitas Gadjah Mada, Yogyakarta.

Thaweethamcharoen, T., Noparatayaporn, P., Sritippayawan, S. \& Aiyasanon, N. (2019). Comparison of EQ-5D-5L, VAS, and SF-6D in
Thai Patients on Peritoneal Dialysis. Value in Health Regional Issues; 18; 59-64.

Wyld, M. L. R., Chadban, S. J. \& Morton, R. L. (2016). Improving Our Understanding of Quality of Life in CKD. American Journal of Kidney Diseases; 67; 820-821.

Yang, F., Lau, T., Lee, E., Vathsala, A., Chia, K. S. \& Luo, N. (2015). Comparison of the PreferenceBased EQ-5D-5L and SF-6D in Patients with EndStage Renal Disease (ESRD). The European Journal of Health Economics; 16; 1019-1026. 